\title{
LEPTIN AND BMI IN OA DEVELOPMENT
}

The role of body weight in the pathogenesis of osteoarthritis (OA) - previously considered the sole factor in the association between obesity and $\mathrm{OA}$-is being re-evaluated as the contribution of adiposity to this process becomes clearer. A new study by Pallu et al. indicates that chondrocyte responsiveness to leptin varies depending on $\mathrm{BMI}$ in patients with OA. "Obesity is associated with a defect in the central action of leptin," explains Nathalie Presle, the study's lead investigator, "which raises the question as to whether or not peripheral tissues, including cartilage, also become resistant to the effects of leptin."

The investigators isolated chondrocytes from articular cartilage samples obtained from the knees of 25 patients with $\mathrm{OA}$, who were classified as either nonobese $\left(\mathrm{BMI} \leq 30 \mathrm{~kg} / \mathrm{m}^{2}\right)$ or obese $\left(\mathrm{BMI}>30 \mathrm{~kg} / \mathrm{m}^{2}\right)$. Stimulation of the cells from nonobese individuals with $100 \mathrm{ng} / \mathrm{ml}$ leptin induced upregulation of type 2 collagen and insulin-like growth factor 1 (IGF-1) mRNA. However, $500 \mathrm{ng} / \mathrm{ml}$ leptin was required for a similar type 2 collagen and IGF-1 mRNA induction in chondrocytes from obese patients. In addition, the gene encoding metalloproteinase inhibitor 2 (TIMP-2) was identified as a target of leptin in chondrocytes from nonobese patients. By contrast, leptin stimulated production of matrix metalloproteinase 13 (MMP-13) mRNA, and not TIMP-2 mRNA, in cells from obese individuals.

Overall, these findings suggest that the BMI-dependent effects of leptin on TIMP-2 and MMP-13 expression in chondrocytes might alter the degenerative process during $\mathrm{OA}$ and enhance cartilage damage in obese patients. "Further investigations of intra-articular administration of leptin in animals with a high-fat diet will be helpful to determine whether chondrocytes change their response to leptin during the development of obesity," says Presle.

Rowan Higgs

Original article Pallu, S. et al. Obesity affects the chondrocyte responsiveness to leptin in patients with osteoarthritis. Arthritis Res. Ther. 12, R112 (2010) 